\title{
BUKU PENUNTUN PRAKTIKUM JARINGAN HEWAN MENGGUNAKAN VIRTUAL LABORATORY
}

\author{
Viola Vinca Valisa ${ }^{1)}$, Evi Suryawati ${ }^{2}$, Arnentis $^{3)}$ \\ E-mail: viola.vinca1582@student.unri.ac.id \\ ${ }^{1) 2) 3)}$ Program Studi Pendidikan Biologi, FKIP, Universitas Riau
}

\begin{abstract}
The most problem occurs in the praticum in the real laboratory, so it's not going well. It can affect the depth of concepts, principles, laws and theories that must be understood by the biology teacher candidates. One of the alternatives that can be done is practicum to use a virtual laboratory. The purpose of research is to develop a practical guidebook for animal tissue materials in practicum activities using virtual laboratories for teacher candidates. This research was conducted at the Laboratory of PMIPA FKIP Riau University in December 2020-May 2021. It used a Research and Development (R\&D) approach with ADDIE model. The instruments used are validation expert and response questionnaires. The results showed that the guide books is good quality and suitable to be used as independent learning resources to increase content knowledge for teacher candidates.
\end{abstract}

Keywords: Guide Book, Animal Tissue, Virtual Laboratory.

\section{PENDAHULUAN}

Pembelajaran biologi tidak hanya menyampaikan teori-teori di dalam kelas ataupun sekadar membaca buku-buku biologi, tetapi juga perlu adanya kegiatan percobaan/ eksperimen/praktikum. Kegiatan praktikum bertujuan untuk memberikan pengalaman nyata kepada mahasiswa calon guru biologi dalam mengimplementasikan kajian teori yang telah ada secara kontekstual. Menurut Lase (2020) bahwa seorang calon guru biologi masa depan diharapkan tidak hanya memiliki kemampuan dalam aspek kognitif saja, melainkan harus memiliki keterampilan dalam hal pengelolaan kegiatan laboratorium. Keterampilan atau kompetensi yang dimaksud diantaranya adalah penguasaan materi praktikum dan memiliki kemampuan dalam melakukan kegiatan praktikum dengan benar. Namun, kegiatan praktikum di laboratorium masih memiliki berbagai permasalahan seperti terbatasnya waktu untuk melakukan eksperimen, keterbatasan persediaan peralatan dan bahan praktikum dan kualitasnya dibawah standar, sehingga kurang memadai dalam menunjang pelaksanaan praktikum. Hal ini dapat bertolak belakang dengan konsep, prinsip, hukum dan teori yang seharusnya dipahami sehingga dapat mempengaruhi kompetensi mahasiswa calon guru biologi.

Penelitian Anif (2013) menunjukkan kompetensi profesional mahasiswa calon guru dalam melakukan praktikum dengan benar memiliki daya serap yang rendah pada kegiatan mendeskripsikan struktur jaringan hewan dan mengaitkan dengan fungsinya. Hal ini juga didukung penelitian Anggani, et al (2016) bahwa berdasarkan pengalamannya mengajar di kelas XI, materi struktur fungsi jaringan hewan adalah salah satu materi yang tergolong sulit dipahami oleh siswa sehingga nilai ulangan pada materi ini biasanya kurang maksimal. Hal ini dapat menjadi salah satu penyebab dari kesiapan guru dalam menjalankan profesinya. Maka dari itu, kualitas guru yang baik berawal dari kesiapan mahasiswa calon guru untuk menjadi guru profesional karena dengan memiliki kesiapan dapat meminimalisir kesalahan yang terjadi. 
Solusi untuk mengatasi permasalahan tersebut adalah dengan menerapkan media pada proses pembelajaran yaitu virtual laboratory. Virtual laboratory adalah laboratorium maya berbasis komputer yang mengintegrasikan berbagai komponen media seperti teks, gambar, animasi, video, suara dan lain sebagainya untuk melakukan suatu kerjasama untuk mencapai tujuan belajar (Nisa, 2018). Virtual laboratory materi jaringan hewan dikemas menjadi aplikasi yang dapat digunakan secara offline memungkinkan dalam menunjang kegiatan praktikum biologi. Tujuan kegiatan praktikum menggunakan virtual laboratory memberi peluang untuk mahasiswa calon guru menggunakannya kapan saja dan dimana saja (belajar mandiri), hingga menemukan dan menyimpulkan suatu konsep materi. Namun, virtual laboratory membutuhkan petunjuk atau penuntun sebagai penunjang dalam memudahkan penggunaannya. Penuntun praktikum berguna untuk memperlancar dan memberikan bantuan informasi atau materi sebagai pegangan bagi siswa dalam melakukan kegiatan praktikum (Alexander, et al., 2018).

Penelitian ini bertujuan untuk menghasilkan buku penuntun praktikum materi jaringan hewan menggunakan virtual laboratory yang berkualitas dan bermanfaat bagi mahasiswa calon guru biologi.

\section{METODE PENELITIAN}

Penelitian ini adalah penelitian Research and Development (R\&D) yang akan mengembangkan produk berupa buku penuntun praktikum materi jaringan hewan dengan mengacu model pengembangan ADDIE (Analyze, Design, Development, Implementatinon, and Evaluation) tetapi penelitian ini hanya dilakukan sampai pada tahap development. Penelitian ini dilaksanakan di Laboratorium PMIPA FKIP Universitas Riau pada bulan Desember 2020-Januari 2021. Instrumen yang digunakan adalah lembar validasi dan angket respon yang bertujuan untuk menilai kualitas dan keterpakaian produk. Validasi produk dilakukan oleh 5 orang validator yang terdiri dari 3 orang dosen Pendidikan Biologi dan 2 guru biologi SMA. Uji coba produk dilakukan kepada mahasiswa calon guru biologi yakni mahasiswa FKIP Biologi Universitas Riau dengan keseluruhan responden sebanyak 30 mahasiswa yang dipilih dengan teknik purposive random sampling. Data pada penelitian ini dianalisis dengan menggunakan teknik analisis deskriptif. Adapun kategori penilaian untuk validasi dan angket respon dapat dilihat pada Tabel 1.

Tabel 1. Kategori Penilaian

\begin{tabular}{clc}
\hline No & \multicolumn{1}{c}{ Kategori } & Skor Penilaian \\
\hline 1. & Sangat Setuju (SS) & 4 \\
\hline 2. & Setuju (S) & 3 \\
\hline 3. & Tidak Setuju (TS) & 2 \\
\hline 4. & Sangat Tidak Setuju (STS) & 1 \\
\hline
\end{tabular}

(Sugiyono, 2019)

Data yang diperoleh kemudian dianalisis menggunakan rumus:

$$
\mathrm{M}=\frac{\sum F x}{\mathrm{~N}}
$$

Keterangan:

$\mathrm{M}=$ Rata-rata penilaian

$\mathrm{N}=$ Jumlah komponen yang divalidasi

$\mathrm{Fx}=$ Skor yang diperoleh

Kriteria rentang skor hasil validasi dapat dilihat pada Tabel 2.

Tabel 2. Kriteria Validitas

\begin{tabular}{cc}
\hline Interval Rata-Rata Skor & Kategori \\
\hline $3,25 \leq \mathrm{x} \leq 4$ & Sangat Valid \\
\hline $2,5 \leq \mathrm{x}<3,25$ & Valid \\
\hline $1,75 \leq \mathrm{x}<2,5$ & Kurang Valid \\
\hline $1 \leq \mathrm{x}<1,75$ & Tidak Valid \\
\hline & (Sugiyono, 2019)
\end{tabular}


Kriteria hasil uji coba terbatas dapat dilihat pada Tabel 3.

Tabel 3. Kriteria Uji Coba Terbatas

\begin{tabular}{cc}
\hline Interval Rata-Rata Skor & Kategori \\
\hline $3,25 \leq \mathrm{x} \leq 4$ & Sangat Baik \\
\hline $2,5 \leq \mathrm{x}<3,25$ & Baik \\
\hline $1,75 \leq \mathrm{x}<2,5$ & Kurang Baik \\
\hline $1 \leq \mathrm{x}<1,75$ & Tidak Baik \\
\hline & (Sugiyono, 2019)
\end{tabular}

\section{HASIL DAN PEMBAHASAN}

Buku penuntun praktikum jaringan hewan sebagai penunjang praktikum menggunakan virtual laboratory untuk mahasiswa calon guru dihasilkan dalam penelitian ini mempunyai karakteristik yaitu: (a) tampilan fisik buku penuntun praktikum memiliki cover/sampul yang menarik, tulisan jelas, dan gambar berwarna, (b) komponen-komponen yang terdapat pada buku meliputi cover, kata pengantar, daftar isi, deskripsi buku, petunjuk penggunaan buku, tata tertib di laboratorium, prosedur praktikum menggunakan virtual laboratory, lembar review laporan penelitian, dan daftar pustaka, (c) lembar kerja praktikum meliputi judul praktikum, dasar teori, tujuan, alat, bahan, dan langkah kerja, (d) format buku menggunakan huruf Bookman Old Style dengan ukuran 12pt, menggunakan EYD yang baik dan benar. Hasil validasi buku penuntun oleh validator ahli berdasarkan aspek struktur materi disajikan pada Tabel 4.

Tabel 4. Hasil Validasi Aspek Struktur Materi

\begin{tabular}{clcc}
\hline No & \multicolumn{1}{c}{ Indikator } & Rerata & Kategori \\
\hline 1 & Deskripsi buku mengarahkan pembaca memahami isi buku & 3,80 & $\mathrm{SV}$ \\
\hline 2 & $\begin{array}{l}\text { Buku penuntun memiliki judul materi untuk memudahkan dalam } \\
\text { mempelajari konsep yang akan dipelajari }\end{array}$ & 3,80 & $\mathrm{SV}$ \\
\hline 3 & $\begin{array}{l}\text { Buku penuntun membantu dalam memudahkan penggunaan virtual } \\
\text { laboratory }\end{array}$ & 3,80 & $\mathrm{SV}$ \\
\hline 4 & $\begin{array}{l}\text { Buku penuntun praktikum sesuai dengan indikator esensial content } \\
\text { knowledge yang harus dikuasai oleh mahasiswa calon guru biologi }\end{array}$ & 3,80 & $\mathrm{SV}$ \\
\hline 5 & $\begin{array}{l}\text { Buku penuntun praktikum dapat meningkatkan rasa ingin tahu dalam } \\
\text { melakukan kegiatan praktikum biologi }\end{array}$ & 3,80 & $\mathrm{SV}$ \\
\hline 6 & Buku penuntun praktikum bermanfaat sebagai sumber belajar mandiri & 3,60 & $\mathrm{SV}$ \\
\hline 7 & Tujuan praktikum pada penuntun praktikum telah sesuai indikator & 3,80 & $\mathrm{SV}$ \\
\hline 8 & Dasar teori menunjang untuk pemahaman & 3,60 & $\mathrm{SV}$ \\
\hline 9 & Langkah-langkah pada penuntun praktikum sudah jelas dan berurutan & 4,00 & $\mathrm{SV}$ \\
\hline$\quad$ Rata-Rata & $\mathbf{3 , 7 7}$ & $\mathrm{SV}$ \\
\hline
\end{tabular}

\section{Keterangan: $S V=$ Sangat Valid}

Berdasarkan Tabel 4 diketahui bahwa materi yang disajikan sudah sesuai dengan topik yang dikembangkan dan mampu memudahkan pengguna dalam melakukan praktikum maya menggunakan virtual laboratory dengan rata-rata sebesar 3,77 kategori sangat valid. Sementara hasil validasi tertinggi terdapat pada indikator 9 yaitu langkah-langkah kegiatan praktikum pada buku penuntun praktikum sudah jelas dan sistematis dengan rerata skor 4,00 kategori sangat valid. Hal ini disebabkan karena langkah-langkah kegiatan praktikum yang disajikan berurutan dari langkah awal hingga akhir praktikum dengan kalimat-kalimat yang ringkas, jelas, dan tepat. Menurut Suryaman (2012) bahwa penalaran berkaitan dengan alur berpikir, sehingga suatu tulisan harus dikembangkan berurutan, sistematis, jelas, dan tegas. Buku ini memuat kompetensi dasar dan indikator esensial content knowledge guru biologi sehingga pembaca mengetahui maksud dari mempelajari buku penuntun praktikum ini. 
Dilihat dari penyajian buku penuntun praktikum hasil pengembangan, buku ini mudah digunakan dan efektif maka membuktikan buku penuntun ini dapat digunakan sebagai sumber belajar mandiri untuk mahasiswa calon guru biologi. Sebagaimana yang dikatakan Supriadi (2015), sumber belajar adalah segala sesuatu yang dapat dimanfaatkan untuk kepentingan kegiatan pembelajaran dengan tujuan untuk meningkatkan efektivitas, efisiensi, mudah dan menyenangkan untuk kelangsungan pembelajaran. Selain aspek struktur materi, dilakukan juga validasi aspek bahasa. Hasil validasi aspek bahasa terhadap buku penuntun dapat dilihat pada Tabel 5.

Tabel 5. Hasil Validasi Aspek Bahasa

\begin{tabular}{clcc}
\hline No & \multicolumn{1}{c}{ Indikator } & Rerata & Kategori \\
\hline 1 & $\begin{array}{l}\text { Tulisan dan bahasa yang digunakan pada buku } \\
\text { penuntun sesuai dengan aturan EYD }\end{array}$ & 3,60 & $\mathrm{SV}$ \\
\hline $\begin{array}{l}\text { Tulisan dan bahasa yang digunakan pada buku } \\
\text { penuntun jelas dan mudah dipahami }\end{array}$ & 3,40 & $\mathrm{SV}$ \\
\hline \multicolumn{2}{c}{ Rata-Rata } & $\mathbf{3 , 5 0}$ & $\mathrm{SV}$ \\
\hline
\end{tabular}

Keterangan: $S V=$ Sangat Valid

Tabel 5 menunjukkan buku penuntun praktikum sudah dirancang dengan bahasa indonesia yang baik dan benar sesuai dengan EYD (Ejaan Yang Disempurnakan) sehingga kalimat yang disajikan pada buku sudah jelas dan dapat dipahami dengan mudah. Menurut Sofiyana (2016) bahasa adalah sarana untuk menyerap dan mengembangkan pengetahuan. Oleh karena itu, penggunaan bahasa dalam mengembangkan suatu buku penuntun juga harus diperhatikan. Selanjutnya aspek yang dinilai dari penuntun praktikum yang dikembangkan yaitu aspek format dan kegrafisan yang dapat dilihat pada Tabel 6.

Tabel 6. Hasil Validasi Aspek Format dan Kegrafisan

\begin{tabular}{clcc}
\hline No & \multicolumn{1}{c}{ Indikator } & Rerata & Kategori \\
\hline 1 & Halaman sampul berkaitan dengan isi buku penuntun praktikum & 3,60 & SV \\
\hline 2 & $\begin{array}{l}\text { Buku penuntun praktikum disusun dengan format yang sistematis dan } \\
\text { jelas }\end{array}$ & 3,80 & SV \\
\hline 3 & Format dan template buku penuntun praktikum memiliki daya tarik & 3,40 & $\mathrm{SV}$ \\
\hline 4 & Sistem penomoran pada buku penuntun jelas dan runtun & 3,60 & $\mathrm{SV}$ \\
\hline 5 & Teks dan ilustrasi sesuai dengan format buku penuntun praktikum & 3,40 & $\mathrm{SV}$ \\
\hline 6 & Layout atau tata letak buku penuntun praktikum tersusun rapi & 3,40 & $\mathrm{SV}$ \\
\hline 7 & Jenis dan ukuran huruf pada buku penuntun sesuai dan jelas & 3,60 & $\mathrm{SV}$ \\
\hline 8 & $\begin{array}{l}\text { Spasi dan paragraf pada buku penuntun praktikum sesuai dan tersusun } \\
\text { rapi }\end{array}$ & 3,60 & $\mathrm{SV}$ \\
\hline 9 & Kontras warna huruf dan background yang digunakan sesuai & 3,20 & $\mathrm{~V}$ \\
\hline & Rata-Rata & $\mathbf{3 , 5 1}$ & SV \\
\hline
\end{tabular}

Keterangan: $S V=$ Sangat Valid

Berdasarkan Tabel 6 diketahui rata-rata hasil validasi buku penuntun pada aspek format dan kegrafisan secara keseluruhan menunjukkan bahwa buku penuntun hasil pengembangan ini memiliki kualitas yang baik dan menarik dari segi visualnya, sehingga mampu menunjang kegiatan praktikum yang dilakukan. Hal ini sesuai dengan pendapat Arsika dan Ramadhan (2015) penuntun praktikum yang memiliki desain yang menarik dapat meningkatkan motivasi belajar berupa percaya diri, perhatian, relevansi, dan kepuasan. Halaman sampul dikemas menggunakan ilustrasi yang berkaitan dengan isi buku penuntun praktikum.

Menurut Andi Prastowo (2012) yang menyatakan halaman cover berisi judul, nama pengarang, gambar sampul, nama departemen, dan tahun terbit. Berikut halaman sampul buku penuntun hasil pengembangan dapat dilihat pada Gambar 1. 


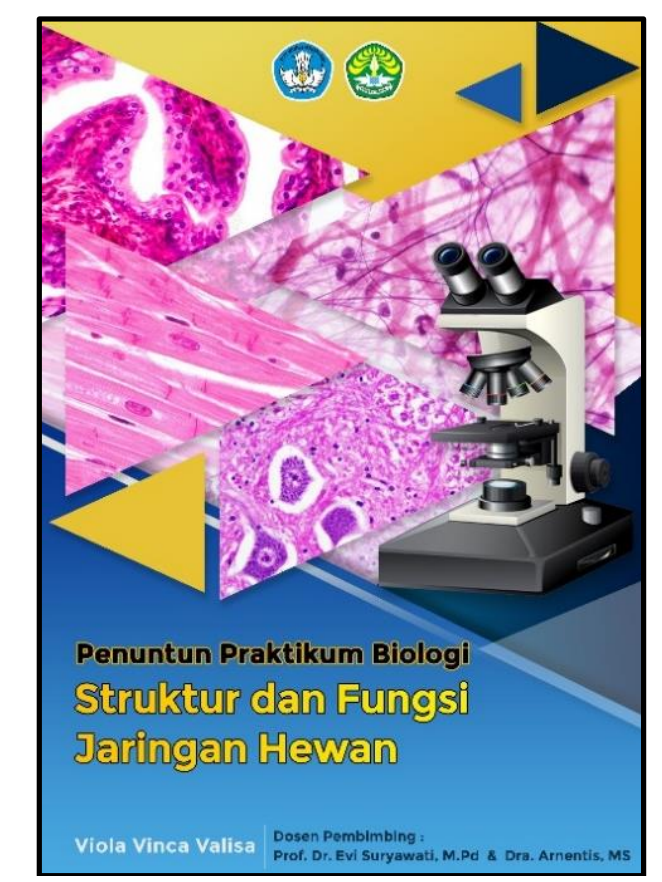

Gambar 1. Tampilan Halaman Sampul

Pada buku penuntun, jenis dan ukuran huruf yang digunakan dipilih sesuai dengan kemudahan dalam keterbacaan dan jelas. Hal ini didukung pernyataan oleh Afridayanti dan Azizah (2020), bahwa penggunaan font (jenis dan ukuran) dapat mempengaruhi pemahaman dan minat pembaca. Aspek terakhir yang dinilai adalah aspek gambar dan ilustrasi pada buku penuntun praktikum yang dapat dilihat pada Tabel 7.

Tabel 7. Hasil Validasi Aspek Ilustrasi dan Gambar

\begin{tabular}{clccc}
\hline No & \multicolumn{1}{c}{ Indikator } & Rerata & Kategori \\
\hline 1 & $\begin{array}{l}\text { Ilustrasi dan gambar pada buku memberikan rangsangan } \\
\text { secara visual yang konkrit kepada pembaca }\end{array}$ & 3,20 & V \\
\hline 2 & $\begin{array}{l}\text { Ilustrasi dan gambar pada buku mendukung untuk } \\
\text { memperjelas konsep }\end{array}$ & 3,20 & V \\
\hline 3 & Gambar yang digunakan memiliki kualitas yang baik & 3,40 & SV \\
\hline & Rata-Rata & $\mathbf{3 , 2 7}$ & SV \\
\hline
\end{tabular}

Keterangan: $S V=$ Sangat Valid; $V=$ Valid

Pada Tabel 7 menunjukkan hasil validasi terhadap ilustrasi dan gambar pada buku penuntun praktikum materi struktur dan fungsi jaringan hewan memperoleh rata-rata sebesar 3,27 kategori sangat valid. Ini menggambarkan bahwa buku penuntun praktikum hasil pengembangan sudah cukup menggambarkan isi/maksud dari informasi yang ingin disampaikan. Menurut Soedarso (2014) mengatakan bahwa ilustrasi pada buku pelajaran mempunyai fungsi untuk menerangkan teks atau suatu keterangan peristiwa baik ilmiah maupun gambar bagian. Ilustrasi dan gambar yang disajikan membuat buku menjadi menarik dan tidak monoton hanya teks saja. Adanya ilustrasi dan gambar ini dapat menimbulkan rangsangan visual seperti ketertarikan dari pembaca untuk memahami isi buku. Menurut Wanti dan Haris (2016), gambar atau lambang visual dapat mengugah emosi dan sikap peserta didik, sedangkan fungsi kognitif media visual atau gambar dapat memperlancar pencapaian tujuan untuk memahami dan mengingat informasi atau pesan yang terkandung dalam gambar. Sama halnya juga untuk memperjelas konsep. Pada buku penuntun ini, ilustrasi dan gambar yang disajikan sudah cukup mendukung untuk memperjelas konsep.

Berdasarkan rata-rata penilaian hasil validasi keseluruhan aspek pada buku penuntun praktikum menunjukkan bahwa buku penuntun praktikum memiliki kualitas yang baik dan berguna 
dalam menunjang kegiatan praktikum yang dilakukan menggunakan virtual laboratory. Kemudian dilanjutkan untuk dilakukan tahap uji coba terbatas.

Uji coba terbatas bertujuan untuk mengetahui respon mahasiswa calon guru terhadap bahan ajar yang telah dikembangkan. Angket respon siswa berisi tiga aspek penilaian diantaranya tampilan, bahasa, dan kegunaan. Adapun hasil uji coba dapat dilihat pada Tabel 8.

Tabel 8. Hasil Rata-Rata Uji Coba Buku Penuntun Praktikum

\begin{tabular}{ccc}
\hline Uji Coba Tahap & Rerata & Kategori \\
\hline I & 3,96 & SB \\
\hline II & 3,86 & SB
\end{tabular}

Keterangan: $S B=$ Sangat Baik

Rata-rata nilai hasil uji coba I dan II pada buku penuntun praktikum yang dikembangkan berada pada ketegori sangat baik (Tabel 8). Hal ini menunjukkan bahwa buku penuntun praktikum hasil pengembangan mendapatkan respon positif dari mahasiswa calon guru biologi karena responden merasa buku penuntun praktikum mempunyai ketertarikan bagi pembaca dan memberi kemudahan dalam melaksanakan kegiatan praktikum jaringan hewan menggunakan virtual laboratory. Buku penuntun praktikum menyajikan materi disertai beberapa gambar yang menarik disusun secara sistematis dan jelas sehingga mudah dipahami oleh mahasiswa calon guru biologi. Menurut Alexander, et al (2018), supaya kegiatan praktikum dapat terlaksana dengan baik diperlukan suatu penuntun praktikum yang sistematis dan efektif.

Buku penuntun praktikum juga dilengkapi dengan soal latihan sesuai materi kegiatan praktikum untuk mengevaluasi pemahaman pembaca. Buku penuntun yang dikemas dalam format pdf memberikan kemudahan bagi pembaca untuk mengakses dan mengulang kembali pemahamannya. Sehingga pembaca dapat mengajarkan kembali materi tersebut. Menurut Ima Aryani (2018) mengatakan bahwa ketersediaan sumber belajar dalam proses pembelajaran dapat memperlancar mahasiswa dalam belajar. Maka secara keseluruhan, buku penuntun praktikum materi struktur dan fungsi jaringan hewan ini secara efektif dapat digunakan sebagai sumber belajar bagi mahasiswa calon guru biologi untuk menambah pengetahuan kontennya dalam melakukan kegiatan praktikum jaringan hewan menggunakan virtual laboratory dan dapat meningkatkan motivasi belajar.

\section{KESIMPULAN}

Buku penuntun praktikum materi jaringan hewan dalam praktikum menggunakan virtual laboratory yang dikembangkan berkualitas dan dapat digunakan sebagai sumber belajar mandiri dalam meningkatkan pengetahuan konten bagi mahasiswa calon guru biologi.

\section{DAFTAR PUSTAKA}

Afridayanti, R. dan Azizah, U. 2020. Validitas Lembar Kerja Peserta Didik (LKPD) Dengan Model Pembelajaran Learning Cycle 7 E Untuk Melatihkan Keterampilan Berpikir Kritis Pada Materi Asam Basa Di Sma Kelas XI. Unesa Journal of Chemical Education, 9(1), 53-58.

Alexander, A., Rahayu, H. M., dan Kurniawan, A. D. 2018. Pengembangan Penuntun Praktikum Fotosintesis Berbasis Audio Visual Menggunakan Program Camtacia Studio di SMAN 1 Hulu Gurung. Jurnal Pendidikan Sains Indonesia, 6(2), 75-82.

Andi Prastowo. 2012. Pengembangan Sumber Belajar. Yogyakarta: Pedagogia.

Anggani, A.D., Paidi, dan Triharjana. 2016. Identifikasi Kesulitan Belajar Struktur Fungsi Jaringan Hewan Pada Siswa Kelas XI SMA Negeri 1 Muntilan. Jurnal Pendidikan Biologi, 5(4), 3950 . 
Anif, S. 2013. Profil Kompetensi Profesional Guru Mapel Biologi Pasca Sertifikasi di Karesidenan Surakarta. Varia Pendidikan, 25(2), 205-223.

Arsika, R. dan Ramadhan, M. F. 2015. Pengembangan Buku Petunjuk Praktikum Ipa Fisika Untuk Meningkatkan Motivasi Belajar Siswa Kelas VII SMPN 1 Lembar Tahun Pelajaran 2014/2015. Jurnal Fisika dan Pendidikan Fisika, 1(1), 10-18.

Lase, N. K. 2020. Analisis Pengetahuan Mahasiswa Prodi Pendidikan Biologi Ikip Gunungsitoli Tentang Peralatan Laboratorium dan Fungsinya. Didaktik, 14(1), 2377-2386.

Nisa, A. K. 2018. Pengaruh Penggunaan Media Laboratorium Virtual Online (Mcgraw-Hill Education) Terhadap Hasil Belajar Biologi Pada Konsep Animalia. Skripsi. FKIP UIN Syarif Hidayatullah Jakarta.

Soedarso, N. 2014. Perancangan Buku Ilustrasi Mahapatih Gajah Mada. Humaniora, 5(2), 561-570.

Sofiyana, M.S., Rohman, F., dan Saptasari, M. 2016. Pengembangan Buku Referensi Bioekologi Berdasarkan Kajian Struktur Komunitas Lumut Epifit di Taman Nasional Bromo Tengger Semeru. Konstruktivisme, 8(2), 301-316.

Supriadi. 2015. Pemanfaatan Sumber Belajar Dalam Proses Pembelajaran. Lantanida Journal, 3(2), 127-139.

Suryaman, M. 2012. Penggunaan Bahasa di Dalam Penulisan Buku Nonteks Pelajaran. Makalah, FSB Universitas Negeri Yogyakarta.

Wanti, A.S.W., dan Haris, H. 2016. Peranan Media Gambar (Visual) dalam Meningkatkan Konsentrasi Belajar Siswa pada Mata Pelajaran PKN di SMPN 1 Sungguminasa Kabupaten Gowa. Jurnal Tomalebbi, 2(2), 29- 34. 